\title{
A bioética na cirurgia
}

\section{The bioethics in surgery}

\author{
TCBC-SP ISAC JORGE FILHO
}

A partir desta edição a revista do CBC passa a contar com uma nova seção: "A Bioética na Cirurgia". Nesse primeiro número estamos publicando um artigo, mas essa não será a tônica. A idéia é que a cada número possamos estar discutindo os dilemas e polêmicas de temas bioéticos do dia a dia do Cirurgião.

Formalmente a Bioética é muito nova. Foi em 1971 que o oncologista norte-americano Van Rensselaer Potter criou o termo, ao publicar o livro "Bioethics: a Bridge to the Future". No entanto as discussões a respeito dos dilemas que levaram a um estudo formal da "Ética da Vida" são muito mais antigos.

Em seus 39 anos a Bioética passou a constituir em uma das áreas de maior crescimento, seja em eventos, seja em publicações. Interesse tão grande mostra que as pessoas entendem que não é possível buscar conhecimentos, divorciando-os da Ética e que nem sempre avanços científicos representam avanços da humanidade.

O cirurgião encontra problemas bioéticos desde aqueles mais gerais, como, por exemplo, os ligados a alocação de recursos públicos que, pela sua exigüidade, deixam pacientes meses e meses em fila esperando tratamentos operatórios, até os mais específicos como a preocupação ética com extensas ressecções intestinais, com curtíssímo intestino remanescente, por saber que todo seu imenso trabalho pode ser jogado por terra pela falta de condições e recursos, na maioria dos locais, para os cuidados que a síndrome do intestino curto, determinada pela ressecção exigirá. É realmente desestimulante para o cirurgião bem formado saber que indiretamente está con- correndo para os problemas pós-operatórios tardios que afligirão esses pacientes. É assim também com as ressecções pancreáticas totais, principalmente nas doenças benignas, com expectativa de vida mais longa. Como ficarão os suportes de insulina e enzimas digestivas que a ressecção vai determinar por toda a vida?

Theodor Billroth colocou um marco na história da Cirurgia ao afirmar que "um bom cirurgião deve, antes de tudo, ser um bom clínico". Estava enterrado o período do cirurgião-barbeiro, do profissional que trabalhava basicamente com as mãos (cirurgia vem de chiros=mão), ficando o trabalho intelectual por conta dos físicos (clínicos, daí o termo em inglês physician). Outro marco na história da Cirurgia foi a valorização dos aspectos psicológicos das doenças, dos doentes, das equipes e, fundamentalmente, a relação cirurgião-paciente. Esse movimento, no Brasil, teve uma série de construtores, como Fernando Paulino e Ruy Ferreira-Santos. O movimento para valorização da Bioética em Cirurgia vem em bom momento, quando se percebe a tendência de se colocar os avanços tecnológicos acima do trabalho intelectual do cirurgião, acima da relação médico-paciente e acima da participação do cirurgião como cidadão ético e atuante. Se você tem dúvidas à respeito desse fenômeno basta analisar os programas dos congressos.

A valorização dos aspectos bioéticos na Cirurgia não significa que os avanços tecnológicos não sejam importantes, mas, simplesmente, que eles não são mais importantes que o raciocínio clínico, que os princípios éticos, que a relação médico-paciente e que a personalidade do cirurgião como pessoa e não como peça de máquina. 